\title{
Bad Debt Influence On The Sustainability Of The Economy Of The Country
}

\author{
Ingrida Grigonyte, M.A. \\ Vilnius Gediminas Technical University, \\ Faculty of Business Management, Lithuania
}

doi: 10.19044/esj.2016.v12n16p79 URL:http://dx.doi.org/10.19044/esj.2016.v12n16p79

\begin{abstract}
The objective of this paper is to evaluate the impact of late commercial payments in business, measured by the EPI index, on the main socio-economic development indicators. Data sources include Eurostat data and annual reports of Intrum Justitia OY. The data used in the research refers to Lithuania. The method of stepwise regression analysis was chosen to test the hypothesized relationship because its parameters have a clear economic interpretation. The study found unfavourable influence of late commercial payments in business on certain socio-economic indicators of the country. This leads to the conclusion that a certain amount of late commercial debts in business can have a significant influence on the economic sustainability of the country. It is necessary to make a deeper/wider research to estimate the influence of late commercial payments on different economic and social indicators as well as measure the magnitude of the influence more precisely. In the absence of similar scientific research, this study provides an insight into the problematic situation of businesses and the influence of this situation on the economic sustainability of the country.
\end{abstract}

Keywords: Late commercial payments, EPI, economic sustainability, payment index

\section{Introduction}

In today's world sustainable development is rapidly growing in importance. No one denies the need for sustainable business practices (Chouinard el al., 2011). An inherent part of sustainable development is economic sustainability. Increasing recognition that the overall goals of environmental conservation and economic development are not conflicting, but can be mutually reinforcing, has prompted calls for 'environmentally sustainable’ economic development (Barbier, 2009). 
The general definition of economic sustainability is the ability of an economy to support a defined level of economic production indefinitely. Sustainable socio-economic development is a core element of the European Union's Sustainable Development Strategy (EU SDS). The strategy sets out the objective of promoting a prosperous, innovative, knowledge-rich, competitive and eco-efficient economy, which provides high living standards and full and high-quality employment throughout the European Union (Eurostat database 2016). It becomes evident that economic sustainability is of critical importance for business partners, customers, employees, suppliers and the society at large.

Good circulation of receivables is important in order for companies (especially small and medium-sized business - SMEs) to support sustainable development. When a company has problems with its clients and suppliers, they may have an impact on its sustainable behaviour, and if the effect is rampant among many market participants, it may affect economic sustainability of the whole country. The main indicators of financial stability of the company, are solvency and liquidity.

Europe's small and medium sized enterprises (SMEs), the lifeblood of the European economy, are most at risk of experiencing liquidity problems (Inrum Justitia 2012) According to the European Commission, SMEs provide two out of three jobs and serve as the driving force for growth, job creation and innovation by providing $85 \%$ of net job growth across Europe. Consequently, a chain reaction increases insolvency of market participants. It is evident that the ability to pay in time to other market participants is very important to the small and medium sized business, otherwise the successful performance of the business can be jeopardised, and, as a consequence, so can the sustainability of the economy.

One of the most widely applicable means used on an international level to determine the ability of businesses to pay in time to other participants of the market, is the European Payment Index (EPI) calculated by one of the largest credit management groups in Europe - Intrum Justitia. Previous research (The author, 2014a, 2014b.) proved the influence of EPI on the main macroeconomic and social indicators of the country.

The sustainable socio-economic development indicator group was chosen for the evaluation as this group indicators form a core element of the European Union's Sustainable Development Strategy (EU SDS).

The objective of this research is to evaluate the impact of business late payments, expressed through EPI, on the main socio-economic development indicators (which are: Real GDP per capita, Net National Income, Investments by Institutional Sector, Household Saving Rate, Total R\&D Expenditure, Real Effective Exchange Rate, Labour Productivity Per Hour Worked, Energy Intensity of the Economy, Total Employment Rate). 
The method of stepwise regression analysis was used. This method was chosen due to clear economic interpretation of its parameters. The years 2004-2012 were chosen for the analysis, because all the data were confirmed and available for this period.

\section{Sustainability, European Payment Index and Socio-economic Indicators}

The lack of timely payments in business is often escalated in reports of credit management companies, even in reports of European Commission. Its negative influence on SME's business, and on the whole economy, is discussed widely in practice. The problem of late commercial payments is proven by the fact that the Directive 2011/7/EU on Combating Late Payment in Commercial Transactions was released. However the polls made by Intrum Justitia (one of the biggest credit management company groups in EU) show that the Late Payments Directive had no significant impact on the late payment situation.

However, despite the problem of late payment being evident in business, there is surprisingly almost no scientific research made by scientists regarding the influence of late commercial payments on the specific indicators of the economics in the EU countries. The author of this paper already made two investigations and published two papers (The author $2014 \mathrm{a}, \mathrm{b}$ ) regarding late payments and main economic and social indicators. Quite significant influence was found between late payments (expressed through EPI) and certain economic indicators.

This paper continues the research and highlights the influence of late commercial payments on main indicators of economic sustainability.

The main idea of economic sustainability is to promote the use of resources in a way that is both efficient and responsible, and likely to provide long-term benefits. In most scenarios, the measure of economic sustainability is presented in monetary terms. The worth of assets and resources in currency is a figure commonly used, as is identifying the amount of return generated by the efficient use of those resources.

Difficulties with the receivables can cause serious obstacles for the sustainable practice of the company. Inability to get receivables on time can have a negative effect on the long-term activity of the business. As a result the lack of changes in the companies can lead to inefficient use of resources, and that might become an obstacle to the sustainable development of the business.

However, economics is traditionally concerned with how we allocate resources. Economic sustainability, then, might be better described as the process of allocating and protecting resources, while ensuring positive social and environmental outcome. One of many goals of economic sustainability is to establish profitability over the long term. A profitable business is much 
more likely to remain stable and continue to operate from one year to the next. Finding out how businesses actually stay in business is a different and altogether more difficult matter (Doane, MacGillivray, 2001; Jorgenson et al., 2014).

The liquidity situation for many businesses in most countries across Europe is now so severe that the likelihood of a rapid rise in firms battling lower sales, more late payments and high costs going bankrupt, has increased dramatically. Liquidity problems are clearly emerging after years of high lost income due to late payments and global recession (Bryan, Tiras et al. 2002; Friewald et al. 2012; Intrum Justitia 2012; Brousseau, et. al. 2014). It is crucial for every company to be able to meet its obligations. Otherwise, it loses credibility and the ability to compete in the market. Solvency indicates the company's ability to meet its short-term liabilities (Jong et al. 2011; Morellec, Nikolov 2012; Pettis 2014) and is a necessary condition for the existence of firms (Wei-Wen 2010;). In broad terms a company's solvency is defined as the potential ability to pay off liabilities with the instruments available (Mortensen 2009; Drehman, Nikolaou 2010, 2013). Sometimes it is defined as the ability to pay taxes (liabilities) (Bebchuk 2009).

Solvency management is essential for the company in order to ensure the success of its business and its reputation. Today reputation becomes the cornerstone in a world full of uncertainties (Bryan, Tiras 2002; Chou et al. 2014; Chrepa 2014). The value of a company is related closely to its solvency and reputation. Empirical studies confirm that financial indicators, especially liquidity and solvency, are very informative measures that can predict the collapse of a company (Bolek, Grosicki 2015; Wolski, Bolek 2016; Kasbi 2009; Huang 2009; Hovakimian, Li 2009; Morellec et al. 2010; He, Milbrandt 2013).

According to Intrum Justitia OY annual reports regarding European payment index, late and non-payments are rife across Europe. Every year Europe's leading provider of Credit Management Services carries out a written survey in 29 European countries, plus Turkey and Russia and calculates the EPI for each country. The results of the survey and the EPI are provided in the annual report. The European Payment Index 2013 paints a picture where the majority of the 29 European countries embraced by the survey have a risk profile that requires immediate actions to avoid further economic deterioration. The inability or unwillingness of consumers, business and authorities to settle their bills on time has severe effects. The amount of receivables that has to be written off as a consequence of not being paid increased from 2.8 percent to 3.0 and reached 350 billion Euro (Intrum Justitia, 2013). The costs of the downturn are becoming patently obvious. EPI survey sends a clear message from the 9800 European enterprises that responded to the survey: $48 \%$ say they have decreased their 
investments in innovation as a consequence of the tightened financial situation, $61 \%$ of respondents have experienced lost sales, $57 \%$ state their liquidity has been impacted by the tough economic conditions and $49 \%$ see no organic growth of their business.

Needless to say, the trend does not leave much room for economy recovery if the European business environment, with small and midsized companies (SMEs) in the forefront, is incapable of innovation and growth (Intrum Justitia, 2013). In the annual report of Intrum Justitia OY 2013 it is firmly stressed that politicians and governments should stop talking about the need to tackle late payments and instead start implementing particular steps towards it. The survey reveals a deep sense of dissatisfaction that not enough is being done to protect business against bad debts. Only a few respondents felt the European Late Payment Directive, now being implemented across the EU, is as yet having any real impact. EPI 2013 survey emphasizes the differences between the northern European countries and the rest of Europe. While countries like Greece, Cyprus, Hungary and Portugal continue to suffer, the Nordic countries together with Germany, Switzerland and Austria show a stable and positive trend with a lower risk profile. Even so, 2013 year's survey indicates that business in the northern regions are also starting to feel the effects of recession.

The 2013 Intrum Justitia European Payment Index survey of 9800 business enterprises representing every business sector in 29 countries in Europe reveals how seriously the economic downturn is affecting European business potential and well-being of today and tomorrow. The survey reveals flagging sales and company liquidity, increased restrictions on credit terms, banks restricting much needed credit, falling staff morale and payment delays.

Although there is considerable variation, by country, in the percentage of receivables being written-off as uncollectable, the late and non-payment problem is widespread everywhere. The only difference is with its severity setting one country apart from another. The number of respondents saying they had to pay additional interest due to late payment has increased in the majority of countries.

According to Intrum Justitia EPI survey in Lithuania, $69 \%$ of respondents mentioned lack of organic growth due to ongoing recession, and $93 \%$ of Lithuanian respondents said that they were paid late because their debtors have financial difficulties. 


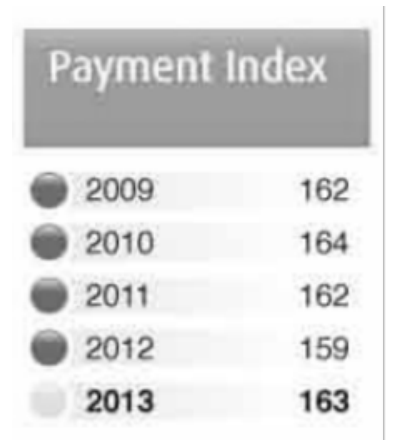

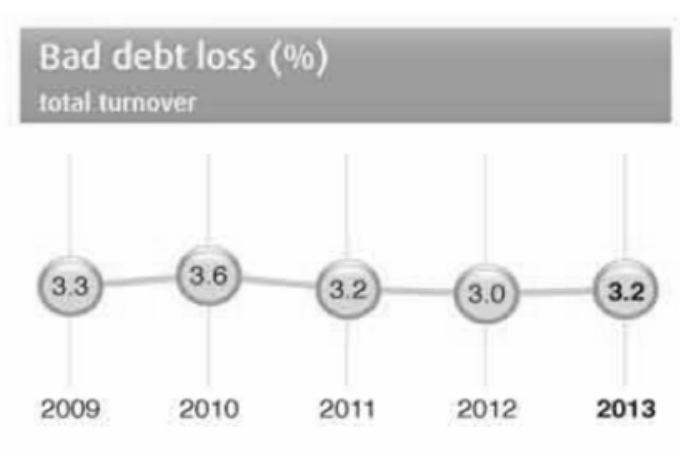

Figure 1. EPI and bad debt loss from total turnover in Lithuania in the years 2009-2013.

Source: Intrum Justitia, 2013.

Also EPI report of 2013 reveals that EPI index in Lithuania increased by 4 points in 2013 compared to 2012 (from 159 to 163), and bad debt loss increased from $3 \%$ to $3.2 \%$ (Figure 1). In this conditions there is very little chance for economic sustainability.

These results show that bad debt situation in Lithuanian business is getting worse. In earlier research (the author 2014a; 2014b) the influence of EPI on main macroeconomic and social indicators of Lithuania was revealed. In order to evaluate the full impact of late payments expressed through EPI on the economic development of the country, more wide and continuous research must be performed. This research is performed in order to determine the influence of EPI on the socio-economic development group of sustainable development indicators of the country.

Alongside technical financial figures, EPI is based on assessments from the companies surveyed. The data forming the basis of the index is generated yearly using a standardized written panel survey. The list of basic data includes: contractual payment terms (in days); effective payment duration (in days); age structure of receivables (DSO); payment loss (in \%); estimation of risk trends; characteristics of the consequences of late payment; causes of late payment. Intrum Justitia calculates the European Payment Index (EPI) every year from eight differently weighted sub-indices, which are based on 21 individual values. The index expresses payment risk between business units in particular countries.

The values of the European Payment Index are as follows: 100 - No payment risks, cash on delivery, pre-payment, no credit 101-129 - Low risk profile, stay alert to keep this profile 130-149 - Medium risk profile, intervention necessary, take action now150-169 - High risk profile, take immediate actions to lower the risk 170-200 - Emergency risk profile.

Each surveyed country was given an individual risk profile. The profile shows the basic criteria for the overall assessment of payment risks (Payment Index) - EPI is calculated in Lithuania as well. 
In this research one group of Sustainable development indicators, the Socio-economic development indicators, was chosen. This group was chosen because it is the first group in headline indicators for EU sustainable development strategy and reflects economic and social prosperity of inhabitants. The socio-economic development indicator group is defined by the European Commission as a core element of the European Union's Sustainable Development Strategy (EU SDS) (Eurostat database 2016). Therefore it is important to understand all the possible factors influencing these indicators.

Socio-economic indicators are divided into three main groups: economic development, innovation and competitiveness and employment. An additional separate group is made of one indicator - real GDP per capita growth rate and totals (percentage change on previous year, Euros per inhabitant). The main indicators chosen for the analysis are given below. Indicators from each group were chosen based on data sufficiency. From employment indicators group the main indicator - total employment rate was chosen, since other indicators have significant correlation with total employment rate, and can distort results of general regression equation by interfering with collinearity of the equation.

Indicators of economic development group are:

- $\quad$ Real GDP per capita

- $\quad$ Net National Income (at market prices);

- $\quad$ Investments by Institutional Sector;

- $\quad$ Household Saving Rate.

Indicators of innovation and competitiveness group are:

- Total R\&D Expenditure (total gross domestic expenditure on research and experimental development as a percentage of gross domestic product).

- $\quad$ Real Effective Exchange Rate;

- $\quad$ Labour Productivity Per Hour Worked;

- $\quad$ Energy Intensity of the Economy.

Indicators of Employment group are:

- $\quad$ Total Employment Rate.

The data used for evaluation covers the period of 2004-2012. This period is defined because of objective limits: the EPI is calculated only from 2004. However, the data is sufficient to obtain reliable results. The data for year 2013 was not included in the evaluation because not all socio-economic development index values were given for 2013 in the Eurostat statistics portal yet. However, during the years 2013-2015 there were no significant changes in EPI of the country. Therefore we might expect the results of this analysis to still be relevant today. 


\section{Material and methods}

The objective of this research is to evaluate the impact of business late payments, expressed through EPI, on the main socio-economic development indicators.

The hypothesis of the research is: the growth of EPI has an unfavourable impact on socio-economic development indicators of the country.

The method of stepwise regression analysis was used. The method was chosen because its parameters have a clear economic interpretation. The linear regression model can be written as:

$$
Y=a+b x+\varepsilon
$$

Where $Y$ is the dependent variable; $x$ - explanatory variable; $a$ and $b$ parameters to be found; $\varepsilon$ - random variable, the deviation from real value.

When the equation of regression is defined, the significance of the equation is tested, as well as validation of the equation and its parameters is performed. Fisher's F-test is used and it is considered that when the significance level is 0.05 , the dependence is very significant, when the level is 0.1 , the dependence is significant, and if $\mathrm{p}>0.1$, the dependence is negligible.

Data that were used in this research were taken from the Eurostat database and cover the years 2004-2012. Data on EPI were taken from the annual reports of Intrum Justitia OY, and cover the years 2004-2012. The years 2004-2012 were chosen because all the data were confirmed and available for this period. The data used refer to Lithuania. Wider research for other EU countries will follow.

\section{Results and discussion}

The stepwise regression analysis between socio-economic development indicators and EPI was performed using the statistical programme RkWard.

In Figure 2 there is given a correlation matrix plot, made using RkWard. Pairwise correlation analysis using Pearson correlation coefficient made using RkWard shows the correlation matrix plot for each parameter pair. Correlation matrix plot in Figure 2 shows the strength of the correlation, the direction of correlation - positive or negative - can be seen in the graph part of the matrix.

The top right half of the matrix shows the correlation coefficients of the variables given in the main diagonal. The number in a given cell gives the correlation coefficient between variables listed in the same row and the same column as that cell. The graphs on bottom left half of the matrix mirrors the graphical expressions of the correlation. 


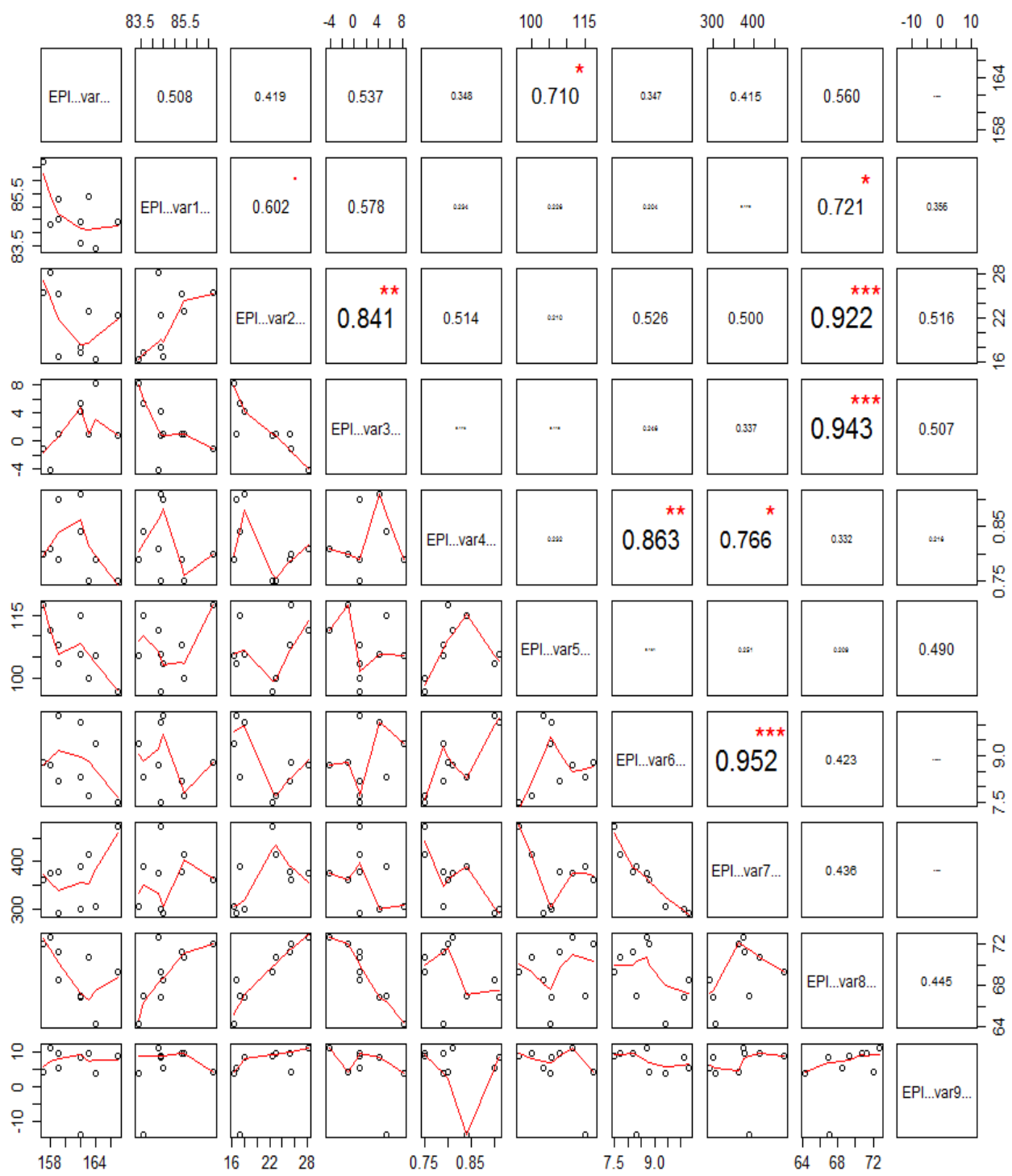

Figure 2. Correlation matrix plot, made using RkWard statistical program Source: own study.

Variables in the picture: var - EPI; var1 - Net National Income; var2 - Investments by Institutional Sector; var3 - Household Saving Rate; var4 Total R\&D Expenditure; var5 - Real Effective Exchange Rate; var6 Labour Productivity Per Hour Worked; var7 - Energy Intensity of the Economy; var8 - Total Employment Rate; var9 - Real GDP per capita, growth rate and totals. ('***': $\mathrm{p}<0.001$-- '**': $\mathrm{p}<0.01$-- '*': $\mathrm{p}<0.05$-- '.": $\mathrm{p}<0.1)$. 
Highly significant correlation $(\mathrm{p}<0.001)$ was found between Total Employment Rate and Investments by Institutional Sector - 0.922, also between Total Employment Rate and Household Saving Rate - 0.943. Household Saving Rate correlates significantly $(\mathrm{p}<0.01)$ with Investments by Institutional Sector -0.841 as well. The significant correlation between these indicators is natural, for household's capacity for investment or future consumption rises along with employment rate, as well as the share of GDP that is used for investment.

Highly significant correlation $(\mathrm{p}<0.001)$ was found between Energy Intensity of the Economy and Labour Productivity per Hour Worked - 0.952. Also Labour Productivity per Hour Worked has significant correlation ( $<<$ 0.01) with Total R\&D Expenditure - 0.863. Significant correlation between these indicators are natural, because it reflects efficiency in the economy and efficiency of means that drive the economy. However, decoupling energy consumption from economic growth is essential for reconciling economic and environmental goals.

There is a strong correlation $(\mathrm{p}<0.05)$ between Total $\mathrm{R} \& \mathrm{D}$ Expenditure and Energy Intensity of the Economy - 0.766, which shows the desire of economy participants to invest into research and development, when price or costs of converting energy into GDP grows higher. Also strong correlation was found between Total Employment Rate and Net National Income -0.721 , but this relation is self explanatory (Figure 2).

Strong correlation was found $(\mathrm{p}<0.05)$ between EPI and Real Effective Exchange Rate -0.710 . The negative slope in the graphs (Figure 2 \& Figure 3) shows that European Payment Index has strong negative influence on country's price or costs competitiveness relative to its principal competitors in international markets. A more detailed study is required for a better explanation of this relationship.

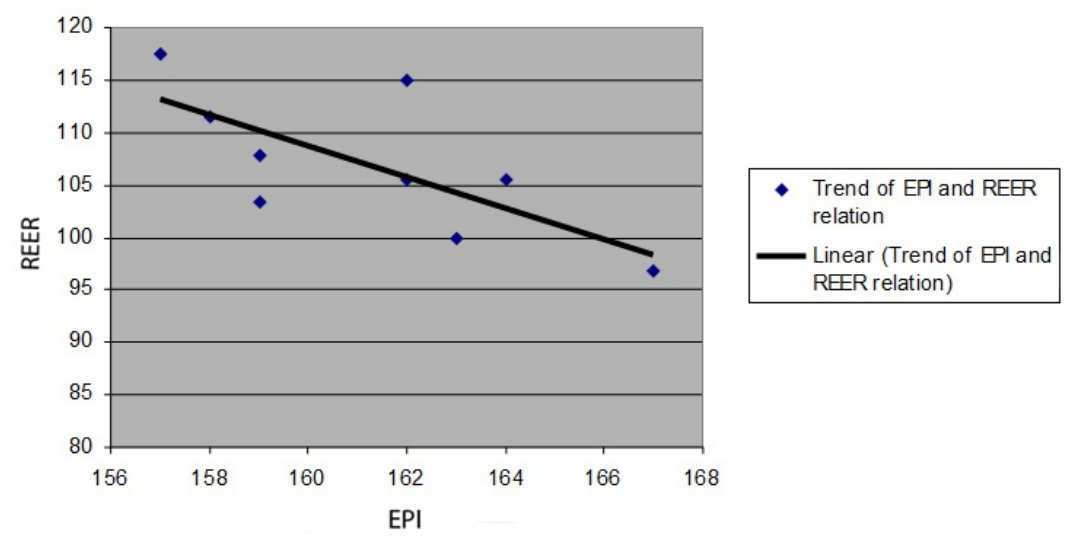

Figure 3. European Payment Index influence on Real Effective Exchange Rate of the country. Source: own study. 
RkWard statistical programme calculates the coefficients $a$ and $b$, assesses their standard error, performs the $\mathrm{F}$ test and assesses the probability with which this result is significant (Table 1 ). If parameter $a>0$, the result of the explanatory variable becomes significant more slowly than the factor of change. In other words, the variation (coefficient of variation) of result is less than the variation factor (The author, 2014a, b). In the results of this research Net National Income, Investments by Institutional Sector, Total R\&D Expenditure, Real Effective Exchange Rate, Labour Productivity Per Hour Worked, Total Employment Rate, Real GDP per capita growth rate and totals have parameter $a>0$, and it shows that these indices change more slowly than EPI. Household Saving Rate and Energy Intensity of the Economy has parameter $a<0$. Calculated $b$ parameter shows that with growth of EPI index all socio-economic indicators fall, except for Household Saving Rate and Energy Intensity of the Economy. These two indicators are rising.

Table 1. Regression analysis of EPI impact to socio-economic development indicators of sustainable indicators group. Source: own study.

\begin{tabular}{|c|c|c|c|c|c|}
\hline Rate or index & $\mathrm{A}$ & $\mathrm{b}$ & $\begin{array}{c}\text { Std. Error (degr. } \\
\text { of freedom) }\end{array}$ & $\begin{array}{c}\text { F statistics (degr. of } \\
\text { freedom) }\end{array}$ & $\begin{array}{c}\text { P value for } \\
\text { equation }\end{array}$ \\
\hline $\begin{array}{c}\text { Net National } \\
\text { Income }\end{array}$ & 110.2007 & -0.1584 & $0.9277(7)$ & $2.4354(1$ and 7$)$ & 0.1626 \\
\hline $\begin{array}{c}\text { Investments by } \\
\text { Institutional } \\
\text { Sector }\end{array}$ & 114.0874 & -0.5752 & $4.3018(7)$ & $1.4937(1$ and 7$)$ & 0.2612 \\
\hline $\begin{array}{c}\text { Household } \\
\text { Saving Rate }\end{array}$ & -96.7391 & 0.6111 & $3.3158(7)$ & $2.8382(1$ and 7$)$ & 0.1359 \\
\hline $\begin{array}{c}\text { Total R\&D } \\
\text { Expenditure }\end{array}$ & 1.8210 & -0.0062 & $0.0581(7)$ & $0.9651(1$ and 7) & 0.3586 \\
\hline $\begin{array}{c}\text { Real Effective } \\
\text { Exchange Rate }\end{array}$ & 345.5730 & -1.4799 & $5.0778(7)$ & $7.0971(1$ and 7) & 0.0323 \\
\hline $\begin{array}{c}\text { Labour } \\
\text { Productivity Per } \\
\text { Hour Worked }\end{array}$ & 25.8648 & -0.1060 & $0.9912(7)$ & $0.9553(1$ and 7) & 0.3609 \\
\hline $\begin{array}{c}\text { Energy Intensity } \\
\text { of the Economy }\end{array}$ & -870.467 & 7.668 & $58.1322(7)$ & $1.4537(1$ and 7) & 0.2671 \\
\hline $\begin{array}{c}\text { Total } \\
\text { Employment } \\
\text { Rate }\end{array}$ & 146.5198 & -0.4797 & $2.4543(7)$ & $3.1913(1$ and 7) & 0.1172 \\
\hline $\begin{array}{c}\text { Real GDP per } \\
\text { capita, growth } \\
\text { rate }\end{array}$ & 28.8021 & -0.1468 & $8.1221(7)$ & $0.0273(1$ and 7) & 0.8734 \\
\hline
\end{tabular}


RKWard program provides a number of reliability parameters of the regression equation: standard error, residual standard error, multiple $\mathrm{R}$ squared, adjusted R squared, F statistics, $\mathrm{P}$ value, degrees of freedom. The program also provides individual coefficients and the accuracy of the parameters: standard error, $t$ value and $P$ value. The equation parameters and the assessment of the overall equation was used. Although data are limited, as the EPI is calculated only from 2004, but it is enough to obtain a reliable regression equation with one variable.

This research cannot be compared to similar prior research, because of the absence of such, to the best knowledge of the author. This research provides initial scientific view of a problematic situation that exists in practice; however, deeper and wider research must follow.

\section{Conclusion}

Economic sustainability is important for business partners, customers, employees, suppliers and the whole society. Good circulation of receivables is crucial to support sustainable development of companies (especially small and medium business - SMEs). When a company struggles to pay its debts, all its measures are aimed at survival.

The data chosen for this research was limited to the main nine socioeconomic development indicators, which are the core elements of the European Union's Sustainable Development Strategy (EU SDS). Wider research must follow.

Absence of delayed receivables and especially absence of bad debts in small and medium business is the main factor that allows small and medium companies to compete successfully and enables not only the maintaining of healthy environment in the market, but may help to seek sustainable development.

The stepwise regression analysis of EPI impact on socio-economic development indicators of sustainable indicators group shows that all socioeconomic indicators, except for Household Saving Rate and Energy Intensity of the Economy, fall when EPI rises. However, the results are not significant.

EPI has a negative influence (correlation -0.710 , of $\mathrm{p}<0.05$ ) on a country's price competitiveness related to its principal competitors in international markets. It can be concluded that EPI index may have eminent effect on cost and price trends, which are included in the indicator of Real Effective Exchange Rate calculation alongside exchange rate movements. However more detailed research is required for more detailed explanation.

In the absence of similar research, this paper provides an initial view of the impact of total late payment on country's overall performance indicators and the influence of late payments on the economic sustainability 
of the country. This insight can help form a better management system for late payments in the businesses of Lithuania or even the EU.

Socio-economic development indicators group that was used in this research is one of ten groups in Sustainable development indicators. Further research should be carried out by evaluating impact of bad debts on other groups of Sustainable development indicators.

Wider research that includes more indicators of various aspects of economy development needs to be carried out.

\section{References:}

Barbier, E.B. (2009). The Concept of Sustainable Economic Development. Environmental Conservation. Published online DOI: http://dx.doi.org/10.1017/S0376892900011449.

Bebchuk, L., Cohen, A., Ferrell, A. (2009). What matters in corporate governance? Review of Financial Studies, 22(2), 783-827. DOI: 10.1093/rfs/hhn099

Bryan, D. M., Tiras, L. S., Wheatley, M. C. (2002). The Interaction of Solvency with Liquidity and its Association with Bankruptcy emergence. Journal of Business Finance \& Ac-counting, 29(7/8), 935-965. DOI: 10.1111/1468-5957.00456

Brousseau, V., Nikolaou, K., Pill, H. (2014). Liquidity risk in euro area money markets. European Central Bank. Retrieved from website: http://www.aueb.gr/conferences/Crete2014/papers/Nikolaou.pdf

Bolek, M., Grosicki, B. (2015). How to Evaluate Financial Liquidity of a Company Using the Discriminant Analysis. European Scientific Journal, 11 (1), 48-69.

Chouinard, Y., Ellison, J., Ridgeway, R. (2011). The Big Idea: The Sustainable Economy. Harvard Business review.

Chou, R. K., Chang, Y., Huang, T. (2014, November 5). Corporate Governance and the Dynamics of Capital Structure: New Evidence. Retrieved from website:

http://sfm.finance.nsysu.edu.tw/20thSFM/pdf/CompletePaper/077-

294631995.pdf

Chrepa, E., Chrysoloras, N. (2014, November 5). Private Bad Debt Buildup Casts Shadow on Greek Rebound. Retrieved from website:

http://www.bloomberg.com/news/2014-09-28/quiet-build-up-of-greek-

private-bad-debt-castsshadow-on-rebound.html

Drehmann, M., Nikolaou, K. (2008). Funding liquidity risk: definition and measurement. Working paper series, 1024, 4 - 47.

Drehman, M., Nikolaou, K. (2010). Funding liquidity risk: definition and measurement. Working Papers, 316, 1-35. 
Doane, D., MacGillivray, A. (2001). Economic Sustainability the business of staying in business. The Sigma project. $R \& D$ report. Retrieved from website: http://projectsigma.co.uk/RnDStreams/RD_economic_sustain.pdf

Friewald, N. R., Subrahmanyam, M. (2012). Illiquidity or credit deterioration: A study of liquidity in the US corporate bond market during financial crises. Journal of financial economics, 18-36. DOI: $10.2139 /$ ssrn.1420294

The author. (2014a).

The Author. (2014b)

He, Z., Milbrandt, K. (2013). Endogenous liquidity and defaultable bonds. NBER WP, 18408, 1-62.

Huang, R., Ritter, J. R. (2009). Testing theories of capital structure and estimating the speed of adjustment. Journal of Financial and Quantitative Analysis, 44, 237-271. DOI: http://dx.doi.org/10.2139/ssrn.938564

Hovakimian, A., Li, G. (2009). Do firms have unique target debt ratios to which they adjust? SSRN Electronic Journal. DOI: 10.2139/ssrn.1138316 Intrum Justitia OY. (2013). European payment index report 2012. Helsinki: madeleine Bosch.

Intrum Justitia OY. (2012). European payment index report 2011. Helsinki: madeleine Bosch.

Jong, D., Verbeek, M., Verwijmeren, P. (2011). Firms' debt-equity decisions when the static tradeoff theory and the pecking order theory disagree. Journal of Banking and Finance, 35, 1303-1314. DOI:10.1016/j.jbankfin.2010.10.006

Jorgenson, D. W., Landefeld, J. S., Schreyer, P. (2014). Measuring Economic Sustainability and Progress. University of Chicago Press.

Kasbi, S. (2009). Ownership concentration and capital structure adjustments. Working Paper. Retrieved from website: http://citeseerx.ist.psu.edu/viewdoc/download?doi=10.1.1.534.7538\&rep=re p1\&type=pdf

Kyioto protocol to the United Nations Framework Convention on Climate Change. (1998). Article 2 .United nations.

Morellec, E., Nikolov, B., Schürhoff, N. (2012). Corporate Governance and Capital Structure Dynamics. The Journal of Finance, 67(3), 803-8480. DOI: 10.1111/j.1540-6261.2012.01735.x

Morellec, E., Nikolov, B., Schurhoff, N. (2010). Corporate Governance and Capital Structure Dynamics: Evidence from Structural Estimation. AFA meeting paper.

Mortensen, T. (2009). Getting cash in. Chartered Accountants Journal, 88(10), 56. 
Pettis, M. (2014, November 5). Bad debt cannot simply be "socialized“. Retrieved from website: http://blog.mpettis.com/2014/07/bad-debt-cannotsimply-be-socialized/

Wei-Wen, W. (2010). Beyond business failure prediction. Expert Systems with Applications, 37:3, 2371-2376. doi:10.1016/j.eswa.2009.07.056

Wolski, R., Bolek, M. (2016). Liquidity - Profitability Relationship Analysed Once Again. The Case Of Poland. European Scientific Journal, 12 (7), 33-46. DOI http://dx.doi.org/10.19044/esj.2016.v12n7p33

www.eurostat.eu Statistics Data Base [previewed on 28-03-2016]. 